\title{
STRATEGI PENGEMBANGAN USAHA IKAN BELUT KERING DI DESA TINOMBALA KECAMATAN ONGKA MALINO KABUPATEN PARIGI MOUTONG PROVINSI SULAWESI TENGAH
}

\section{DEVELOPMENT STRATEGY OF DRIED EELS IN TINOMBALA VILLAGE, ONGKA MALINO DISTRICT, PARIGI MOUTONG REGENCY CENTRAL SULAWESI PROVINCE}

\author{
Ahsan Mardjudo ${ }^{1 *}$, Wika Indah Pratiwi Djamal ${ }^{1}$ \\ ${ }^{1}$ Dosen Program Studi Agrobisnis Perikanan, Fakultas Perikanan, Universitas Alkhairaat, \\ Jl. Diponegoro, No. 39, Palu 94221, Sulawesi Tengah Indonesia
}

\begin{abstract}
ABSTRAK
Penelitian bertujuan untuk menganalisis strategi pengembangan usaha pengeringan ikan belut di Desa Tinombala Kecamatan Ongka Malino Kabupaten Parigi Moutong Provinsi Sulawesi Tengah. Pengambilan data dalam penelitian ini dilakukan dengan metode pengamatan dan wawancara secara langsung dengan pemilik usaha pengeringan ikan belut. Analisis data melalui pendekatan SWOT dan deskriptif kualitatif. Hasil penelitian ini menunjukkan bahwa secara teknis proses pengeringan ikan belut dimulai dari penimbangan, mematikan ikan belut, penyiangan, pencucian, penirisan, penusukan belut, penyimpangan dengan es batu, penjemuran, pengovenan dan penyimpanan. Hasil SWOT diperoleh gambaran bahwa strategi pengembangan ikan belut kering memiliki aspek kekuatan yaitu dukungan persawahan sebagai lingkungan belut, sarana dan prasarana cukup memadai, masa produksi yang cepat, keterampilan masyarakat, hubungan kerjasama dengan pedagang luar daerah. Sementara peluangnya adalah tersedianya pemasaran, persyaratan mutu ikan belut kering, tidak ada pesaing, permintaan yang cukup tinggi, dan memiliki konsumen tetap. Untuk aspek kelemahannya keterbatasan modal, hasil produksi belum optimal, belum adanya surat izin usaha, belum mempunyai tempat usaha yang tetap, bahan baku tidak selalu tersedia cukup setiap satu kali produksi, sedangkan ancaman adalah menurunnya permintaan produk, peningkatan harga bahan baku, biaya pengiriman yang tinggi, habisnya stok ikan belut di sawah.
\end{abstract}

Kata kunci: strategi pengembangan, ikan belut kering, parigi moutong

\section{ABSTRACT}

This study aims to analyze the development strategy of eel drying business in Tinombala Village, Ongka Malino District, Parigi Moutong Regency, Central Sulawesi Province. Collecting data in this study was carried out by using the method of observation and direct interviews with the owner of the eel drying business. Data analysis using SWOT approach and qualitative descriptive. The results of this study indicate that technically, the drying process of eels starts from weighing, killing the eels, weeding, washing, draining, puncturing the eels, irrigation with ice cubes, drying, oven and storage. The SWOT results show that the dry eel development strategy has a strength aspect, namely the support of rice fields as an eel environment, adequate facilities and infrastructure, fast production period, community skills, cooperative relationships with traders outside the region. Meanwhile, the opportunities are availability of marketing, quality requirements for dried eel fish, no competition, high demand, and having regular customers. For aspects of weakness, limited capital, production results are not optimal, there is no business license, do not have a permanent place of business, raw materials are not always available enough for one production, while the threat is a decrease in product demand, an increase in the price of raw materials, and the cost of shipping. high, the shortage of eel fish stocks in the rice fields.

Keywords: development strategy; dried eel fish; Parigi Moutong

\footnotetext{
${ }^{*}$ Penulis Korespondensi.

E-mail: ahsan.mardjudo@gmail.com

Telp: +62-82192416776
} 


\section{Pendahuluan}

Ketahanan pangan merupakan salah satu pilar penopang keberlanjutan pemerintahan negara dan bangsa Indonesia (Mulyani dan Agus, 2017) dan merupakan landasan pembangunan Nasional yang sudah semestinya dijadikan prioritas oleh pemerintah. Secara umum Indonesia sudah mampu menyediakan sebagian besar kebutuhan pangannya dari produksi domestik, namun kemandirian beberapa komoditas strategis lainnya mutlak harus dicapai dan dipertahankan. Pemerintah Indonesia telah mencanangkan menjadi negara yang berswasembada pangan pada periode tahun 2014-2019 (Mulyani dan Agus, 2017).

Indikator dalam ketahanan pangan yaitu kecukupan dan stabilitas ketersediaan pangan, akses keterjangkauan terhadap pangan, kualitas serta keamanan pangan, dan keberlanjutan pangan. Membangun ketahanan pangan dapat dilakukan dengan pemanfaatan sumberdaya lokal secara maksimal. Sistem ketahanan pangan diarahkan untuk menjaga ketahanan dan kemandirian pangan daerah dengan mengembangkan kemampuan produksi daerah yang didukung kelembagaan ketahanan pangan yang mampu menjamin pemenuhan kebutuhan pangan yang cukup di tingkat rumah tangga, baik dalam jumlah, mutu, keamanan, maupun harga yang terjangkau, yang didukung oleh sumbersumber pangan yang beragam sesuai dengan keragaman lokal (Rizka, 2015).

Sumber pangan alternatif yang beragam dapat menyediakan pangan yang cukup bagi masyarakat dan sebagai sumber pangan lokal yang masih dilakukan secara tradisional, baik dari aspek budidaya maupun pengelolaan dan percepatan adopsi teknologi pemanfaatan sumber pangan lokal yang diharapkan dapat menjadi salah satu penyangga ketahanan pangan di daerah (Wahid dan Sri, 2009).

Sektor perikanan merupakan salah satu sumber pangan alternatif yang sangat potensial bagi Indonesia, mengingat bahwa luas lautnya $2 / 3$ kali dari luas daratannya. Subsektor ini terdiri dari dua kelompok besar yakni perikanan tangkap dan perikanan budidaya. Perikanan budidaya akhirakhir ini mulai banyak diusahakan, baik budidaya ikan air laut, air payau maupun budidaya ikan air tawar. Salah satu bahan pangan perikanan adalah hasil perikanan air tawar. Berbagai jenis komoditas perikanan air tawar yang telah dikembangkan masyarakat antara lain ikan mas, ikan nila, ikan mujair, ikan gabus, ikan lele, ikan belut, dan lainnya. Diantara komoditas tersebut, ikan belut dianggap cukup menjanjikan meskipun konsumen ikan belut masih sangat terbatas karena kecenderungan mengkonsumsi ikan belut dapat dipengaruhi oleh beberapa faktor, antara lain pemahaman nilai gizi yang kurang, dan faktor kebiasaan masyarakat.

Ikan belut termasuk dalam jenis ikan air tawar yang pasarnya masih sangat terbuka lebar baik secara nasional maupun internasional. Jenis ikan ini memiliki kandungan gizi yang sangat tinggi sehingga bisa diterima oleh pasar dengan baik dalam bentuk masih segar maupun dalam bentuk pengeringan. Kandungan gizi ikan ini sangat cukup baik bagi kesehatan tubuh manusia, diantaranya sebagai sumber protein dan sumber energi (Suciati Hasballah, 2015).

Komoditas ikan belut memiliki peluang pasar yang cukup prospektif, terutama diorientasikan ke pasar Internasional sebagai komoditas ekspor. Negara-negara pengimpor ikan belut antara lain Hongkong, Perancis, Belgia, Spanyol, Belanda, Jerman, Jepang, dan Denmark. Tidak kalah dengan pasar luar negeri, di Indonesia pun ada usaha kecil dan menengah (UKM) yang mempunyai peran yang sangat strategis dalam pembangunan ekonomi Nasional (Palupi $d k k$., 2014).

Ikan belut ini dapat dibuat menjadi berbagai macam olahan, seperti unagi donburi, unagi kabayaki, janggu hui, jellied eels, you bao shan hu, ikan belut kering petai cabe ijo, goreng ikan belut kering, ikan belut kering balados, ikan belut kering goreng sambal kentang, balado ikan belut kering kentang dan ikan belut kering lado mudo (https://cookpad.com/id 2019).

Seiring berjalannya waktu ikan belut mulai dikenali banyak orang dengan kelezatan dan protein yang terkandung di dalamnya, sehingga permintaan pun semakin banyak, baik dalam bentuk pengeringan ikan belut maupun prodak makanan lainnya. Biasanya ikan belut hanya dikonsumsi sebagai bahan lauk pauk, rasanya pun cukup enak dan tidak kalah dengan ikan-ikan lainnya dan dapat divariasikan menjadi berbagai macam prodak makanan.

Variasi hasil pengeringan ikan belut merupakan salah satu cara penganekaragaman jenis prodak hasil perikanan dari bahan baku yang belum atau sudah dimanfaatkan dengan tetap memperhatikan faktor mutu dan gizi sebagai usaha peningkatan konsumsi prodak perikanan, 
baik kualitas maupun kuantitas dan peningkatan nilai jualnya (Palupi $d k k, 2014$ ),

Salah satu desa pengembang usaha ikan belut kering ini di kabupaten Parigi Moutong adalah di Desa Tinombala. Desa Tinombala adalah salah satu Desa Transmigrasi yang masyarakatnya didominasi oleh masyarakat Suku Jawa. Desa Tinombala dan sekitarnya (Desa Kotaraya dan Desa Kayu Agung) merupakan wilayah persawahan. Luas areal sawah di Kabupaten Parigi Moutong 32.595,4 Ha (BPS, 2018).

\section{Metode Penelitian}

Penelitian ini dilaksanakan di Desa Tinombala Kecamatan Ongka Malino Kabupaten Parigi Moutong Provinsi Sulawesi Tengah.

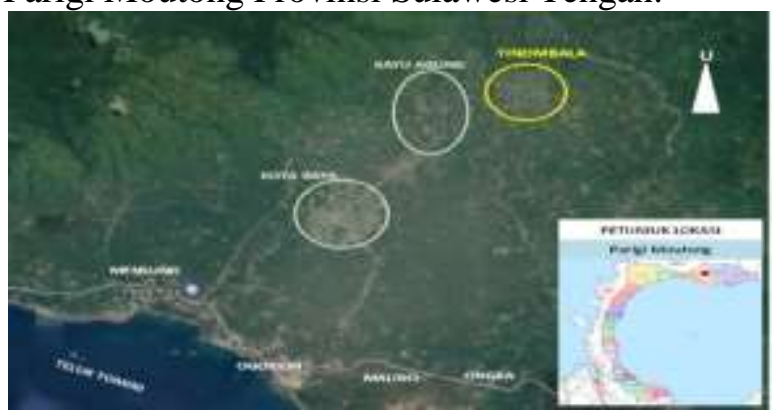

Gambar1. Peta Desa Tinombala

Jenis data yang dikumpulkan dalam penelitian ini adalah data primer dan data sekunder. Data primer adalah data yang diperoleh melalui pengamatan wawancara secara langsung dengan pemilik usaha yang ada di Desa Tinombala Kecamatan Ongka Malino Kabupaten Parigi Moutong sebagai responden. Sedangkan data sekunder adalah data yang dikumpulkan dari Desa setempat dan dari BPS Kabupaten Parigi Moutong.

Penelitian ini bersifat studi kasus, dimana pemilik usaha ikan belut kering hanya ada satu yang ada di Desa Tinombala. Olehnya itu, peneliti melakukan penelitian pada usaha tersebut secara intensif dan mendetail, kemudian data yang diperoleh di tabulasi dan kemudian dianalisa dengan pendekatan SWOT.

Menurut Rangkuti (2013) bahwa analisis SWOT merupakan suatu cara untuk mengidentifikasi berbagai faktor secara sistematis dalam rangka merumuskan strategi suatu usaha. SWOT kepanjangan dari strength (kekuatan), weakness (kelemahan), opoortunity (peluang) dan threat (ancaman).

\section{Hasil dan Pembahasan}

\section{Analisis Strategi Pengembangan Usaha Ikan Belut Kering}

Analisis strategi pengembangan usaha ikan belut kering dengan menggunakan Analisis SWOT. Identifikasi faktor internal dan eksternal yang dirumuskan dalam upaya menganalisis strategi pengembangan usaha ikan belut kering di Desa Tinombala diuraikan sebagai berikut :

\section{A. Analisis Faktor Internal}

1. Kekuatan (strength)

a. Dukungan Persawahan Sebagai Lingkungan Belut

Pelaku usaha di Desa Tinombala memanfaatkan area persawahan yang sudah selesai dipanen untuk dijadikan sebagai tempat pengumpulan bahan baku. Luas wilayah di Kecamatan Ongka Malino sebesar 380,24 Km² yang tersebar di sepanjang garis pantai kabupaten Parigi Moutong, lahan yang sudah dimanfaatkan sebesar 4.189 Ha (BPS, 2018) Sehingga lahan persawahan yang dapat dimanfaatkan masih sangat besar. Kondisi ini merupakan peluang sekaligus tantangan di masa depan dalam meningkatkan pemanfaatan lahan dan peningkatan kapasitas produksi.

b. Sarana dan Prasarana Cukup Memadai

Berdasarkan hasil penelitian bahwa sarana dan prasarana produksi utama untuk usaha ikan belut kering yang berada di Desa Tinombala yaitu rumah produksi, bak penampungan, timbangan, pisau, keranjang, loyang, bambu, tempat penjemuran dan oven manual. Sarana dan prasarana yang digunakan berasal dari pemilik usaha sendiri.

c. Masa Produksi Yang Cepat

Masa produksi ikan belut kering yang ada di Desa Tinombala ini terbilang cukup cepat karena proses pembuatannya hanya membutuhkan waktu 1 minggu untuk mendapatkan $20 \mathrm{~kg}$ ikan belut kering.

d. Keterampilan Masyarakat

Keterampilan yang diajarkan dalam proses pembuatan ikan belut kering ini dimulai dari persiapan bahan baku sampai pengemasan. Pelatihan dilakukan secara langsung yang diajarkan oleh pemilik usaha.

5. Hubungan Kerjasama Dengan Pedagang Luar Daerah

Permintaan produk ikan belut kering berasal dari luar daerah di Sulawesi Tengah sehingga pemilik usaha melakukan hubungan kerjasama dengan pedagang luar daerah untuk pemasaran produk ikan belut kering. 


\section{Kelemahan (weaknesses)}

\section{a. Keterbatasan Modal.}

Pengembangan usaha ikan belut kering di Desa Tinombala saat ini terbentur pada permasalahan dalam penyediaan modal usaha, dimana pelaku usaha belum mampu memenuhi kebutuhan modal untuk memperluas/menambah stok produksinya.

b. Hasil Produksi Belum Optimal

Produksi ikan belut kering di Desa Tinombala saat ini belum optimal karena pada produksinya dalam 3 bulan dihasilkan $100 \mathrm{~kg}$ ikan belut kering jadi untuk pertahun produksi yang bisa dihasilkan hanya sebanyak $400 \mathrm{~kg}$ sedangkan permintaan dalam setahun harus memenuhi 1 ton ikan belut kering.

c. Belum Adanya Surat Izin Usaha

pemilik usaha ikan belut kering di Desa Tinombala saat ini belum memperoleh izin usaha dikarenakan usaha saat ini masih dalam skala rumah tangga dan peralatan yang digunakan masih menggunakan alat alat sederhana rumah tangga.

d. Belum Mempunyai Tempat Usaha Yang Tetap pemilik usaha ikan belut kering di desa Tinombala saat ini belum memiliki rumah produksi untuk usahanya tersebut, karena sampai saat ini pemilik usaha masih kekurangan modal dalam usahanya.

e. Bahan Baku Tidak Selalu Tersedia Cukup Setiap Satu Kali Produksi

Bahan baku ikan belut setiap kali produksi tidak selalu cukup karena kurangnya bahan baku yang ada di daerah persawahan di Desa Tinombala sehingga pemilik usaha selalu mendatangkan bahan baku dari berbagai daerah untuk memenuhi pembuatan produksi.

\section{B. Analisis Faktor Eksternal}

\section{Peluang (Opportunities)}

a. Tersedianya pemasaran.

Pemasaran ikan belut kering di Desa Tinombala termasuk mudah karena pemilik usaha langsung menjualnya ke Jakarta. Di Jakarta pun siap menampung berapapun jumlah ikan belut kering yang telah di yang dihasilkan oleh pemilik usaha dari Desa Tinombala.

\section{b. Persyaratan mutu ikan belut kering}

Pemilik usaha dapat menampung semua hasil produksi ikan belut kering dengan persyaratan ikan belut harus benar-benar kering dan bersih dari kotoran-kotoran yang menempel. Untuk mendapatkan hasil yang maksimal maka pemilik usaha harus memperhatikan persyaratan tersebut. c. Tidak ada pesaing
Usaha ikan belut kering yang berada di Kecamatan Ongka Malino hanya ada di Desa Tinombala. Hal ini menjadi peluang untuk dapat mengembangkan usaha ikan belut kering ini.

d. Permintaan Yang Cukup Tinggi

Tingkat permintaan ikan belut kering di berbagai daerah selalu meningkat tiap tahunnya sehingga pemilik usaha terlalu sulit untuk memenuhi permintaan perusahaan.

e. Memiliki konsumen tetap

Ikan belut kering ini memiliki konsumen tetap sehingga pemilik usaha tidak lagi harus memasarkan produknya sehingga setelah pengiriman ikan belut kering langsung di antarkan kepada konsumennya.

\section{Ancaman (Threats)}

a. Menurunnya Permintaan Produk, Peningkatan Harga Bahan Baku, Biaya pengiriman yang tinggi, Habisnya Stok Ikan Belut Di Sawah

Menurunnya permintaan produk di sebabkan karena kurangnya permintaan pasar dan bahan baku yang tidak selalu ada sehingga konsumen mulai melirik produk lain untuk dikonsumsi.

b . Peningkatan Harga Bahan Baku

Bahan baku sangat berpengaruh terhadap produksi yang dihasilkan. Pemilik usaha ikan belut kering di Desa Tinombala masih perlu memesan ikan belut dari berbagai daerah disulawesi tengah untuk memperoleh kecukupan produksi dan harga yang ditawarkan dari pengepul cukup tinggi karena ikan belut cukup sulit untuk di dapatkan.

c. Biaya pengiriman yang tinggi

Biaya sewa transportasi yang dilakukan pemilik usaha di desa Tinombala untuk pengiriman ikan belut kering lewat jalur darat cukup tinggi karena pemilik usaha belum mempunyai alat transportasi sendiri sehingga harus menyewa mobil dengan lama peminjaman bisa sampai 2 hari. Sedangkan untuk pengiriman lewat jalur udara pemilik usaha harus membayar biaya kargo dan biaya packing untuk produk ikan belut kering.

d. Habisnya Stok Ikan Belut Di Sawah

Habisnya stok ikan belut di sawah bisa saja di sebabkan karena terlalu seringnya ikan belut di ambil sehingga populasi ikan belut semakin hari semakin sedikit yang bisa saja mengakibatkan ikan belut sawah tidak dapat berkembang.

\section{Penentuan Bobot}

Bobot setiap faktor internal dan eksternal di tentukan dengan metode paired comparison yaitu 
1 = jika indikator faktor horizontal kurang penting dibandingkan indikator faktor vertikal

$2=$ jika indikator faktor horizontal sama penting dibandingkan indikator faktor vertikal

3 = jika indikator faktor horizontal lebih penting dibandingkan indikator faktor vertikal

4 = jika indikator faktor horizontal sangat penting dibandingkan indikator faktor vertikal

Identifikasi terhadap faktor-faktor internal usaha berupa kekuatan dan kelemahan yang berpengaruh terhadap pengembangan usaha ikan belut kering di Desa Tinombala. Dengan memasukkan hasil identifikasi kekuatan yang diberi simbol (S) dan kelemahan yang diberi simbol (W) sebagai faktor strategis internal kemudian diberikan nilai bobot. Dapat dilihat pada Tabel 1. Sedangkan identifikasi terhadap faktor-faktor eksternal yang terdiri dari peluang dan ancaman dengan memasukkan hasil identifikasi peluang yang diberi simbol $(\mathrm{O})$ dan ancaman yang diberi simbol (T). Untuk lebih jelasnya dapat dilihat pada Tabel 1.

Tabel 1. Penilaian Bobot Faktor Strategis Internal Usaha Ikan Belut Kering di Desa Tinombala

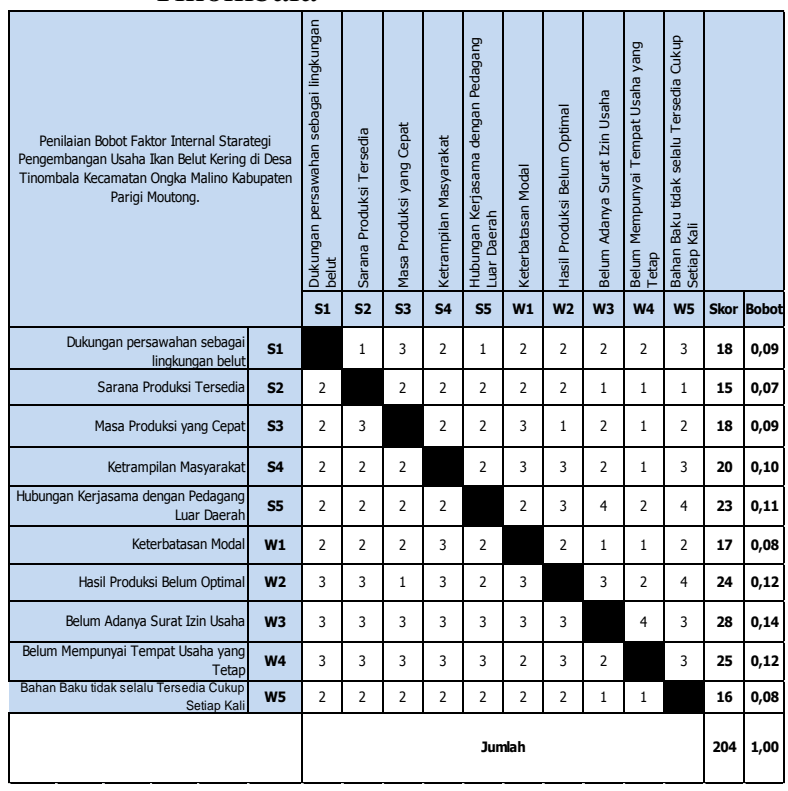

Tabel 2. Penilaian Bobot Faktor Strategis Eksternal Usaha Ikan Belut Kering di Desa Tinombala

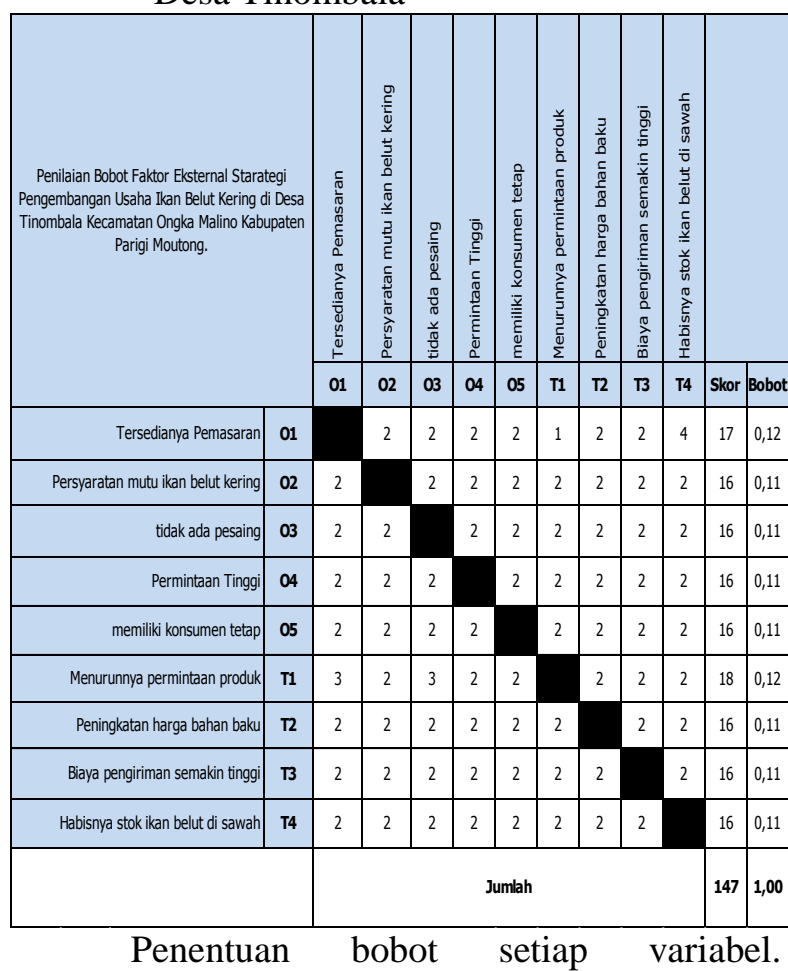

Pemberian nilai/bobot dan rating dilakukan secara subjektif kepada setiap unsur SWOT dengan kisaran. Metode tersebut digunakan untuk memberikan penilaian terhadap bobot setiap faktor internal dan eksternal. Bobot setiap faktor internal dan eksternal dapat ditentukan dengan metode Paired Comparison (Kinnear 1991 dalam Pudjiwaskito 2005).

\section{Pemberian Rating}

Setelah diperoleh bobot dari masingmasing faktor strategis internal dan faktor strategis eksternal, selanjutnya dilakukan penentuan peringkat (rating) antara 1- 4. Kemudian rating setiap faktor tersebut dikali dengan bobot untuk memperoleh skor pembobotan yang tercantum dalam matriks IFE dan EFE. Pemberian rating disajikan pada Tabel 3 dan Tabel 4 .

Berdasarkan Tabel 4 dapat diketahui bahwa diantara faktor internal, faktor kekuatan yang paling besar adalah hubungan kerja sama dengan pedagang luar daerah dengan skor 0,45. Hal tersebut menunjukkan bahwa hubungan kerja sama sangat penting dalam pengembangan usaha ini. Sehingga usaha ini perlu dikembangkan lagi dengan cara memanfaatkan lahan persawahan yang masih tersedia dan menggunakan kekuatan 
lain yang dapat menjadi kekuatan tambahan dalam pengembangan usaha ikan belut kering.

Tabel 3. Matriks IFE Internal Usaha Ikan Belut Kering di Desa Tinombala

\begin{tabular}{|c|c|c|c|c|}
\hline \multicolumn{2}{|r|}{ Faktor Strategis Internal } & \multirow{2}{*}{ Bobot } & \multirow{2}{*}{ Rating } & \multirow{2}{*}{ Skor } \\
\hline & ekuatan & & & \\
\hline 1. & Dukungan persawahan sebagai lingkungan belut & 0,09 & 4,00 & 0,35 \\
\hline 2. & Sarana Produksi Tersedia & 0,07 & 4,00 & 0,29 \\
\hline 3. & Masa Produksi yang Cepat & 0,09 & 3,00 & 0,26 \\
\hline 4. & Ketrampilan Masyarakat & 0,10 & 3,00 & 0,29 \\
\hline 5. & Hubungan Kerjasama dengan Pedagang Luar Daerah & 0,11 & 4,00 & 0,45 \\
\hline & Jumlah & & & 1,66 \\
\hline \multicolumn{2}{|c|}{ B. Kelemahan } & & & \\
\hline 1. & Keterbatasan Modal & 0,08 & 4,00 & 0,33 \\
\hline 2. & Hasil Produksi Belum Optimal & 0,12 & 3,00 & 0,35 \\
\hline 3. & Belum Adanya Surat Izin Usaha & 0,14 & 3,00 & 0,41 \\
\hline 4. & Belum mempunyai tempat usaha yang tetap & 0,12 & 3,00 & 0,37 \\
\hline 5. & Bahan baku tidak selalu tersedia cukup setiap kali produksi & 0,08 & 4,00 & 0,31 \\
\hline & Jumlah & & & 1,78 \\
\hline
\end{tabular}

Sedangkan faktor-faktor kelemahan yang memiliki skor paling tinggi adalah belum adanya surat izin usaha dengan skor 0,41. Pengembangan usaha ikan belut kering di Desa Tinombala masih terbentur pada permasalahan dalam surat izin usaha, dimana pemilik usaha belum mampu memenuhi syarat dan kriteria sebuah usaha sehingga usaha ini masih berada dalam usaha skala rumah tangga. Dengan adanya surat izin usaha diharapkan mampu meningkatkan hasil produksi dan dapat berkembang menjadi lebih besar.

Tabel 4. Matiks EFE External Usaha Ikan Belut Kering di Desa Tinombala

\begin{tabular}{|c|c|c|c|}
\hline Faktor Strategis Eksternal & \multirow{2}{*}{ Bobot } & \multirow{2}{*}{ Rating } & \multirow{2}{*}{ Skor } \\
\hline A. Peluang & & & \\
\hline \begin{tabular}{l|l} 
1. & Tersedianya Pemasaran \\
\end{tabular} & 0,12 & 3,00 & 0,35 \\
\hline 2. Persyaratan mutu ikan belut kering & 0,11 & 2,00 & 0,22 \\
\hline 3. tidak ada pesaing & 0,11 & 3,00 & 0,33 \\
\hline 4. Permintan Tinggi & 0,11 & 4,00 & 0,44 \\
\hline $\begin{array}{ll}\text { 5. } & \text { memiliki konsumen tetap } \\
\end{array}$ & 0,11 & 3,00 & 0,33 \\
\hline Jumlah & & & 1,65 \\
\hline B. Ancaman & & & \\
\hline 1. Menurunnya permintaan produk & 0,12 & 3,00 & 0,37 \\
\hline \begin{tabular}{l|l} 
2. & Peningkatan harga bahan baku
\end{tabular} & 0,11 & 4,00 & 0,44 \\
\hline 3. Biaya pengiriman semakin tinggi & 0,11 & 3,00 & 0,33 \\
\hline 4. Habisnya stok ikan belut di sawah & 0,11 & 4,00 & 0,44 \\
\hline Jumlah & & & 1,56 \\
\hline Jumlah Total & & & 3,22 \\
\hline
\end{tabular}

Berdasarkan tabel diatas diketahui bahwa diantara faktor eksternal, faktor peluang yang paling besar adalah permintaan tinggi dengan skor 0,44 Ini berarti usaha pengembangan ikan belut kering di Desa Tinombala memiliki kesempatan peluang yang sangat besar dengan tersedianya pemasaran. Sedangkan faktor ancaman yang paling besar adalah habisnya stok ikan belut di sawah dengan skor 0,44 .
Berdasarkan tabel matriks IFE dan matriks EFE diketahui bahwa skor kekuatan sebesar 0,45, kelemahan sebesar 0,41 , peluang sebesar 0,44 dan ancaman sebesar 0,44 jumlah dari skor analisis internal secara keseluruhan yaitu 0,86 sedangkan jumlah analisis eksternal secara keseluruhan yaitu 0,88 Maka nilai tersebut menunjukkan bahwa faktor-faktor eksternal lebih berpengaruh terhadap pengembangan usaha ikan belut kering di Desa Tinombala dibandingkan dengan faktor internalnya namun keduanya masih saling terkait antara faktor internal dan eksternal.

\section{Analisis Strategi}

Menyusun analisis strategi usaha ikan belut kering di Desa Tinombala menggunakan matrik SWOT. Alat yang digunakan untuk menggambarkan bagaimana faktor eksternal yang dihadapi dipadukan dengan faktor internal yang dimiliki yaitu dengan pembentukan matrik SWOT. Disajikan pada Tabel 5.

Tabel5.Matriks SWOT Strategi Pengembangan usaha Ikan Belut Kering

\begin{tabular}{|c|c|c|}
\hline & Kekuatan (S) & Kelemahan (W) \\
\hline Eksternal & $\begin{array}{l}\text { 1. Dukungan } \\
\text { persawahan } \\
\text { sebagai } \\
\text { lingkungan belut } \\
\text { 2. Sarana produksi } \\
\text { tersedia } \\
\text { 3. Masa Produksi } \\
\text { yang Cepat } \\
\text { 4. keterampilan } \\
\text { masyarakat } \\
\text { 5. hubungan } \\
\text { kerjasama } \\
\text { dengan pedagang } \\
\text { luar daerah } \\
\end{array}$ & $\begin{array}{ll}\text { 1. } & \text { Keterbatasan Modal } \\
\text { 2. } & \text { Hasil Produksi Belum } \\
& \text { Optimal } \\
\text { 3. } & \text { Belum Adanya Surat Izin } \\
\text { Usaha } \\
\text { 4. Belum mempunyai tempat } \\
\text { usaha yang tetap } \\
\text { 5. } \begin{array}{l}\text { Bahan baku tidak selalu } \\
\text { tersedia cukup setiap kali } \\
\text { produksi }\end{array}\end{array}$ \\
\hline Peluang $(\mathrm{O})$ & Strategi SO & Strategi WO \\
\hline $\begin{array}{ll}\text { 1. } & \text { Tersedianya } \\
& \text { Pemasaran } \\
\text { 2. } & \text { Persyaratan mutu } \\
\text { ikan belut kering } \\
\text { 3. } & \text { tidak ada pesaing } \\
\text { 4. } & \text { Permintaan Tinggi } \\
\text { 5. } & \text { memiliki konsumen } \\
& \text { tetap }\end{array}$ & $\begin{array}{ll}\text { - } & \text { Mengembangkan } \\
\text { teknologi } \\
\text { produksi (S1, S2, } \\
\text { S3, O1, O4, O5) } \\
\text { - Peningkatan } \\
\text { kualitas produksi } \\
\text { untuk menjaga } \\
\text { kerjasama dengan } \\
\text { pasar yang sudah } \\
\text { ada (S4, S5, O2, } \\
\text { O3) }\end{array}$ & $\begin{array}{ll} & \text { Meningkatkan permodalan } \\
\text { usaha ( O4,W1,W3,W4) } \\
\text { Meningkatkan hasil produksi } \\
\text { (O4, W2, W5) } \\
\text { Memperluas dan } \\
\text { Mempertahankan pemasaran } \\
\text { yang ada (W2, O1, O2, O3, } \\
\text { O5) }\end{array}$ \\
\hline Ancaman (T) & Strategi ST & Strategi WT \\
\hline $\begin{array}{l}\text { 1. } \begin{array}{l}\text { Menurunnya } \\
\text { permintaan produk }\end{array} \\
\text { 2. Peningkatan harga } \\
\text { bahan baku } \\
\text { 3. Biaya pengiriman } \\
\text { semakin tinggi } \\
\text { 4. Habisnya stok ikan } \\
\text { belut di sawah }\end{array}$ & 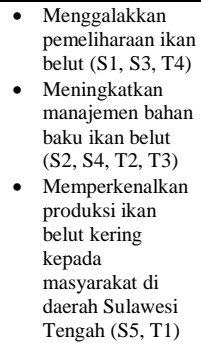 & $\begin{array}{l}\text { - Membuat legalitas usaha (W2 } \\
\text {, W5, T1, T2) } \\
\text { - Menyusun perencanaan usaha } \\
\text { dan sesuai dengan } \\
\text { perkembangan pasar ikan } \\
\text { belut kering (W1, W3, W4, } \\
\text { W5, T1, T3, T4) }\end{array}$ \\
\hline
\end{tabular}

Menurut Rangkuti (2013) bahwa analisis SWOT membandingkan antara faktor internal, yaitu kekuatan (stregth), dan kelemahan 
(weakness) dengan faktor eksternal yaitu peluang (opportunity), dan ancaman (threats). Faktor internal dimasukan kedalam matriks yang disebut matriks faktor IFAS (Internal Strategic Faktor Analisis Summary). Faktor eksternal dimasukan kedalam matriks yang disebut matriks faktor eksternal atau EFAS (Eksternal Strategic FaktorAnalisis Summary).

\section{Penentuan Rangking Alternatif Strategi}

Penentuan prioritas strategi usaha pengembangan ikan belut kering dilakukan dengan memperhatikan faktor-faktor yang saling terkait. Rangking prioritas strategi ditentukan berdasarkan urutan jumlah skor terbesar sampai terkecil dari semua strategi yang ada. Perangkingan alternatif strategi dapat dilihat pada Tabel 6.

Tabel6. Perangkingan Alternatif Strategi Berdasarkan Matriks SWOT pada Usaha Ikan Belut Kering di Desa Tinombala.

\begin{tabular}{|c|c|c|c|c|}
\hline $\mathrm{N}_{0}$ & Alternatif Strategi & $\begin{array}{c}\text { Keterkaitan Antar } \\
\text { Unsur SWOT }\end{array}$ & Skor & Rangking \\
\hline 1. & $\begin{array}{l}\text { Menyusun Perencanaan Usaha dan Sesuai Dengan Perkembangan } \\
\text { Pasar Ikan Belut Kering }\end{array}$ & $\begin{array}{c}\text { W1, W3, W4, W5, } \\
\text { T1, T3, T4 }\end{array}$ & 2,13 & 1 \\
\hline 2. 1 & Mengembangkan Teknologi Produksi & $\begin{array}{c}\text { S1, } \mathrm{S} 2, \mathrm{~S} 3,01,04 \\
05\end{array}$ & 2,11 & 2 \\
\hline 3. 1 & Memperluas dan Mempertahankan Pemasaran Yang Ada & W2, 01, 02, 03, 05 & 1,45 & 3 \\
\hline 4. $\stackrel{\mathrm{P}}{\mathrm{P}} \mathrm{P}$ & $\begin{array}{l}\text { Peningkatan Kualitas Produksi untuk Menjaga Kerjasama dengan } \\
\text { Pasar yang sudah ada }\end{array}$ & $\$ 4, \$ 5,02,03$ & 1,39 & 4 \\
\hline 5. 1 & Meningkatkan Manajemen Bahan Baku Ikan Belut & $\$ 2, S 4, \mathrm{~T} 2, \mathrm{~T} 3$ & 1,34 & 5 \\
\hline 6.1 & Meningkatkan Permodalan Usaha & 04, W1, W3, W4 & 1,20 & 6 \\
\hline 7. 1 & Membuat Legalitas Usaha & $\mathrm{W} 2, \mathrm{~W} 5, \mathrm{~T} 1, \mathrm{~T} 2$ & 1,16 & 7 \\
\hline 8. 1 & Menggalakkan Pemeliharaan Ikan Belut & S1, S3, T4 & 1,14 & 8 \\
\hline 9. 1 & Meningkatkan Hasil Produksi & 04, W2, W5 & 0,91 & 9 \\
\hline $10 . \mid \begin{array}{l}1 \\
1\end{array}$ & $\begin{array}{l}\text { Memperkenalkan Produksi Ikan Belut Kering kepada Masyarakat di } \\
\text { Daerah Sulawesi Tengah }\end{array}$ & $\mathrm{S} 5, \mathrm{Tl}$ & 0,82 & 10 \\
\hline
\end{tabular}

Berdasarkan skor dari penyusunan strategi diperoleh ranking setiap strategi. Ranking tersebut menunjukkan urutan alternative strategi sebagai berikut:

1. Menyusun Perencanaan usaha dan sesuai dengan perkembangan pasar ikan belut kering. Perencanaan usaha adalah hal yang sangat penting dalam memulai ataupun mengembangkan suatu usaha. Usaha belut kering di Desa Tinombala membutuhkan perencanaan yang baik dalam mengembangkan usahanya sesuai dengan kecenderungan pernimtaan pasar.

Perencanaan usaha tersebut diharapkan untuk menangani masalah kebutuhan modal (W1), membuat usaha menjadi resmi secara administrative dengan adanya surat izin usaha (W3), membuat tempat usaha yang tetap (W4), dan menangani permasalahan bahan baku tidak selalu tersedia cukup setiap kali produksi (W5). Adanya perencanaan juga dapat mengantisipasi ancaman menurunnya permintaan produk (T1) dimasa mendatang, biaya pengiriman semakin tinggi (T3) dan habisnya stok ikan belut di sawah (T4).

2. Rangking yang ke 2 adalah mengembangkan teknologi produksi.

Pengembangan teknologi produksi untuk meningkatkan produk belut kering. Hal ini karena adanya dukungan persawahan sebagai lingkungan belut (S1) di Desa Tinombala dan sekitarnya sangat luas yang merupakan potensi adanya belut. Sarana produksi tersedia tersedia saat ini (S2), dapat terus dikembangkan, karena kelebihan masa produksi belut kering yang cepat (S3). Pengembangan teknologi produksi juga dijamin oleh tersedianya pemasaran $(\mathrm{O} 1)$, dengan permintaan yang tinggi (O4), selain itu juga sudah memiliki konsumen yang tetap (O5).

3. Rangking yang ke 3 adalah memperluas dan mempertahankan pemasaran yang ada.

Untuk memperluas dan mempertahan pemasaran, hasil produksi yang saat ini belum optimal (W2) harus ditingkatkan. Peluangnya adalah tersedianya pemasaran $(\mathrm{O} 1)$, baik yang sudah bersifat tetap maupun peluang pasar yang mungkin akan didapat. Mempertahankan pasar juga sesuai dengan ketentuan persyaratan mutu ikan belut kering $(\mathrm{O} 2)$ yang secara nasional menjadi syarat umum antara pedagang belut kering, Peluang mempertahankan pemasaran ini didukung oleh tidak ada pesaing usaha belut kering (O3) dan memiliki konsumen tetap (O5).

4. Rangking yang ke 4 adalah peningkatan kualitas produksi untuk menjaga kerjasama dengan pasar yang sudah ada.

Kualitas hasil produksi dapat dilakukan dengan adanya ketrampilan masyarakat (S4) yang sudah terbiasa mengolah belut kering. Kualitas produksi yang baik juga dapat dilakukan karena adanya hubungan kerjasama dengan pedagang luar daerah (S5). Hal ini akan membuat permintaan akan terus meningkat. 
Peluang yang dapat dikembangkan adalah adanya keharusan persyaratan mutu ikan belut kering (O2) yang menjamin pasar. Hal ini dengan leluasa dapat dilakukan oleh usaha belut kering karena usaha tersebut belum ada pesaing (O3) di Parigi Moutong maupun di Sulawesi Tengah.

5. Rangking yang ke 5 adalah meningkatkan manajemen bahan baku ikan belut.

Manajemen bahan baku juga sangat menentukan produk belut kering yang akan dihasilkan. Hal ini dapat dilakukan karena sarana produksi belut kering sudah tersedia (S2), namun masih perlu ditingkatkan. Keterampilan masyarakat (S4) menjadi modal dalam menangani bahan baku. Penangnan bahan baku juga akan mengefisienkan produksi agar tidak terjadi kerugian dalam pembelian bahan baku karena peningkatan harga bahan baku (T2). Bahan baku yang berasal dari luar daerah memerlukan biaya pengiriman yang tinggi, demikian juga biaya pengiriman produk semakin tinggi (T3).

6. Rangking ke 6 adalah meningkatkan permodalan usaha.

Ketersediaan modal sangat penting dalam meningkatkan produksi, mengingat permintaan tinggi untuk ikan belut kering saat ini (O4). Kelemahan keterbatasan modal (W1) menjadi kendala dalam mengembangkan usaha dan jaringan pemasaran. Kelemahan ini juga dipengaruhi karena usaha ini belum mempunyai surat izin usaha (W3), dan usaha ini belum mempunyai tempat usaha yang tetap (W4), sehingga berpengaruh terhadap lemahnya perencanaan sebagai syarat yang harus dipenuhi untuk meningkatkan modal usaha baik dari perbankan maupun investor (pemilik modal).

7. Rangking ke 7 adalah membuat legalitas usaha.

Tanpa adanya legalitas atau izin usaha, suatu usaha akan susah berkembang. Ditengah besarnya potensi bahan baku, hasil pengeringan ikan belut saat ini berproduksi belum optimal (W2). Belum adanya legalitas juga menjadi ancaman yang harus diatasi untuk menghindari menurunnya permintaan produk (T1) hal ini karena tidak ada kepercayaan orang, lembaga, atau pasar terhadap perusahaan tersebut. Legalitas usaha juga akan menjamin keberlansungan usaha dalam menjaga produk dipasaran mengingat biaya produksi semakin meningkat termasuk harga bahan baku ikan belut yang semakin naik (T2).

8. Rangking ke 8 adalah menggalakkan pemeliharaan ikan belut

Usaha belut kering dapat mendorong pemeliharaan belut oleh masyarakat sekitar Desa Tinombala sehingga permasalahan bahan baku belut basah dapat diatasi. Kekuatan terbesar adalah adanya dukungan persawahan sebagai lingkungan belut (S1). Keberadaan bahan baku meskipun dalam jumlah yang banyak dapat meningkatkan volume produksi karena masa produksi belut kering relative cepat (S3). Hal ini juga dapat menghindarkan kemacetan produksi akibat habisnya stok ikan belut di sawah (T4), selain itu dapat mendatangkan keuntungan bagi pemelihara belut karena pemeliharaan belut tidak memerlukan perlakukan khusus yang rumit..

9. Rangking ke 9 adalah meningkatkan hasil produksi.

Adanya permintaan yang tinggi terhadap ikan belut kering (O4) membuat pengusaha belut kering harus meningkatkan jumlah (kuantitas) produksinya. Hasil produksi belum optimal (W2) bukan saja jumlah (kuantitas) namun juga mutu (kualitas) yang harus dikembangkan sesuai keinginan pasar. Permasalah yang paling mendasar dalam peningkatan produksi ini adalah bahan baku tidak selalu tersedia cukup setiap kali produksi (W5), namun hal ini dapat ditangani melalui perluasan pemesanan bahan baku atau penambahan volume penampungan bahan baku.

10.Rangking ke 10 adalah memperkenalkan produksi ikan belut kering kepada masyarakat di daerah Sulawesi Tengah.

Manfaat ikan belut sebagai produk pangan harus diketahui oleh masyarakat sehingga produk tersebut dapat dipasarkan pada masyarakat didaerah (S5). Meskipun masyarakat lokal Sulawesi Tengah belum terbiasa mengkonsumsi belut, namun ikan belut merupakan bahan baku yang dapat diolah kembali menjadi berbagai jenis makanan. Mendorong konsumsi hasil perikanan air tawar (termasuk ikan belut) dapat mengantisipasi menurunnya permintaan produk (T1) yang selama ini hanya dipasarkan diluar daerah Sulawesi Tengah. 


\section{Kesimpulan}

Hasil analisis SWOT menjelaskan bahwa strategi pengembangan usaha ikan belut kering dari faktor eksternal, faktor peluang yang paling besar adalah permintaan tinggi dengan skor 0,44 Ini berarti usaha pengembangan ikan belut kering di Desa Tinombala memiliki kesempatan peluang yang sangat besar dengan tersedianya pemasaran. Sedangkan faktor ancaman yang paling besar adalah habisnya stok ikan belut di sawah dengan skor 0,44 .

Berdasarkan tabel matriks IFE dan matriks EFE diketahui bahwa skor kekuatan sebesar 0,45 , kelemahan sebesar 0,41 , peluang sebesar 0,44 dan ancaman sebesar 0,44 jumlah dari skor analisis internal secara keseluruhan yaitu 0,86 sedangkan jumlah analisis eksternal secara keseluruhan yaitu 0,88 Maka nilai tersebut menunjukkan bahwa faktor-faktor external lebih berpengaruh terhadap pengembangan usaha ikan belut kering di Desa Tinombala dibandingkan dengan faktor internalnya namun keduanya masih saling terkait antara faktor internal dan eksternal.

Pengembangan usaha pengeringan ikan belut di Desa Tinombala Kecamatan Ongka Malino Kabupaten Parigi Moutong dapat dilakukan dengan beberapa alternatife strategi yaitu; (1) menyusun perencanaan usaha dan sesuai dengan perkembangan pasar ikan belut kering, (2) mengembangkan teknologi produksi,(3) memperluas dan mempertahankan pemasaran yang ada, (4) peningkatan kualitas produksi untuk menjaga kerjasama dengan pasar yang sudah ada, (5) meningkatkan manajemen bahan baku ikan belut, (6) meningkatkan permodalan usaha, (7) membuat legalitas usaha, (8) menggalakkan pemeliharaan ikan belut, (9) meningkatkan hasil produksi, (10) memperkenalkan produksi ikan belut kering kepada masyarakat di Daerah Sulawesi Tengah.

\section{Daftar Pustaka}

BPS, 2018, BPS Provinsi Sulawesi Tengah

Mulyani A dan Agus F,. 2017. Kebutuhan dan Ketersediaan Lahan Cadangan Untuk Mewujudkan Cita-Cita Indonesia Sebagai Lumbung Pangan Dunia Tahun 2045. Balai Besar Penelitian dan Pengembangan Sumberdaya Lahan Pertanian Bogor.

Palupi, Hamidah S, dan Yuriani, 2014. Upaya peningkatan pendapatan kelompok usaha belut melalui variasi hasil olahan dan kemasan di godean. Jurnal Inotek Volume 18 Nomor $1: 109-119$.

Pudjiwaskito D. I. 2005. Kajian Pengelolaan Dan Pengembangan Ekowisata Sumber Air Panas Ciater, Subang, Jawa Barat. Skripsi Fakultas Perikanan dan Ilmu Kelautan, Institut Pertanian Bogor.

Rangkuti F., 2013. Teknik Membedah Kasus Bisnis Analisis SWOT Cara Perhitungan Bobot, Rating, dan OCAI. Penerbit PT. Gramedia Pustaka Utama. Jakarta.

Rizka A.A., 2015. Kajian Pemanfaatan Sumberdaya Pangan Lokal Terhadap Ketahanan Pangan Rumah Tangga Kabupaten Kulon Progo.

Suciati, Hasballah, 2015. Prospek Usaha Budidaya Belut Yang Menjanjikan Untung Besar.

Wahid A.R dan Martina Sri Lestari,. 2009 Pemanfaatan Komoditas Pangan Lokal Sebagai Sumber Pangan Alternatif. Jurnal Pertanian Papua.

Cookpad.com/id, 2019. Resep Belut kering https://cookpad.com/id/cari/belut\%20kering . Diakses tanggal 14 Januari 2020 pukul 18.32 . 